\title{
Impact of Temperature and Rainfall Change on Epidemics Caused by Plant Viruses: A Review
}

\author{
Bayissa Regassa \\ Ethiopia Institute of Agricultural Research, Ambo Agricultural Research Center, \\ P. O. Box 37, Ambo, Ethiopia
}

\begin{abstract}
Plant virus diseases are one of the limiting factors to crop productivity by diminishing the quantity, quality and responsible for significant economic losses worldwide. The Epidemic of plant virus diseases is the result of interactions between virus, host plant, vector, and environmental factors. Changes in host plants and insect vector dynamics that result from temperature and rainfall change could have an influence on the spread of plant viruses. The rising of temperature and heat stress increase the susceptibility of host plants to virus infection and accelerates the fitness of viruses to cause disease. The increasing temperature also changes insect vector population dynamics by accelerating insect phenology, causing earlier and prolonged colonization because it makes appropriate environmental conditions for the insect vectors. Insect populations of most virus vectors build up more rapidly in areas with high temperatures and high relative humidity and decline at low temperature. In addition, the rising temperatures can increase the efficiency of virus transmission from infected to healthy plants by insect vectors. An increasing frequency of heavy rainfall events is likely to slow the virus prevalence and incidence by washing insect vectors, thus reducing vector density. Flooding within annual crop growing period enhances the subsequent growth of weed and volunteer crop plant which act as reservoirs of insect vectors and the viruses, and its occurrence outside growing seasons increases subsequent growth of such reservoirs.
\end{abstract}

Keywords: Host plant; Vectors; Virus epidemics

DOI: $10.7176 / \mathrm{JEES} / 12-1-01$

Publication date: January $31^{\text {st }} 2022$

\section{Introduction}

Plant virus diseases are among the major affecting agriculture productions worldwide and have estimated economic losses of greater than $\$ 30$ billion per year (Sastry and Zitter, 2014). The challenge that the increasing rapidity of global warming and climate instability cause to mankind's ability to manage pests and diseases of cultivated plants. Since the start of the industrial period in 1750, the global average concentration of carbon dioxide $\left(\mathrm{CO}_{2}\right)$ in the atmosphere has increased by $41 \%$, methane by $160 \%$, and nitrous oxide by $20 \%$ (Jones, 2016). Climate change which composed of increased atmospheric $\mathrm{CO}_{2}$, temperature and rainfall/water availability has important consequences on crop growth and quality as well as the interactions among plants, pests and diseases. Plant viruses are an important part of these interactions as they can have a devastating effect on food quality and yields. The major climatic drivers for changing the environmental fate and behaviour of plant protection products are rainfall seasonality and intensity, and increased temperatures (Bloomfield et al., 2006).

Viruses have diverse temperature optima that are a number of being adapted to warmer environmental areas and the others to a cooler temperature for multiplication within the host plants. These optimum temperatures are highest in plant viruses adapted to infect plant hosts growing in lowland tropical environmental conditions and lowest in viruses adapted to cold environmental areas, for example, those in cool temperate areas or at high altitude in mountainous regions. Different species of virus vectors and host plants also have varied temperature optima under which they flourish, some being adapted to warmer climates and others to cooler ones (Jones, 2016). These induced changes all affect the way viruses and vectors interact with their plant hosts and influence the spatial and temporal dynamics of virus epidemics.

\section{Plant Virus Epidemics}

The diseases caused by plant viruses are the most important menace to the productivity and profitability of a wide range of crops worldwide. Plant virus disease epidemic results from interactions between host plant, virus, vector and environmental factors (Geering and Randles, 2012). The artificial plant communities created for agriculture are less stable, and severe virus epidemics are common, especially where monoculture is practiced. The Extent of epidemics in crops and yield losses differ widely with geographical regions and year. The main driving factors are including the magnitude of primary virus source within the crop; vector first arrival time relative to crop emergence; abundance and activity of vectors in the crop; climatic factors, including influences of the temperature and rainfall (Thackray et al., 2004). The losses and the resulting financial damage can be limited by managing plant virus epidemics using measures that reduce virus infection sources or suppress virus spread (Jones, 2004, Regassa et al., 2020).

Factors such as host plants, viruses, vector, environment, time, and people's activities (Agrios, 2005) regulate 
the intensity of epidemics. The ability of plant virus disease to spread and make a significant epidemic depends on each of these components remaining permissive, that is, none limiting. Rapidly-expanding global climatic change creates favorable conditions for development and increased spread of plant virus diseases due to direct or indirect impacts on population dynamics of virus-transmitting insect vectors (Pautasso et al., 2012; Geering and Randles, 2012).

Having epidemiological knowledge of plant virus disease is the most important for each virus pathosystem which involves collecting information on the nature of the primary virus infection sources, how the virus spreads into and within crops, how the virus spreads over distance to invade new sites and how it survives outside the main growing period. Then, a clear picture is required of the factors driving plant virus epidemics concerned, which are the most important that favoring the spread and which delay its epidemics (Jones, 2001).

Factors favoring epidemics include infection source within the crop and widely distributed, external infection source nearby, growing monocultures, extended growing periods, successive plantings of short-lived crops allyear-round, planting susceptible cultivars, planting cultivars with long growing periods, no crop rotation, poor control of weeds and 'volunteer' plants, old infected plantings left in a farm field, temperatures favor virus multiplication and vector (Jones, 2004).

\section{Influence of Temperature Change}

\subsection{Host plant and viruses}

The increasing of temperature alters host plant physiology, metabolic pathways, nutritional status, phenology and morphology (Canto et al., 2009; Jones and Barbetti, 2012). The heat stress and rising mean temperature increase the susceptibility of host plants to virus infection and decrease and rather provides the fitness of viruses to cause infection (Mitchell et al., 2005). Increased temperature in addition alters the rates of plant virus multiplication, systemic movement of individual viruses present in mixed infection (Jones, 2016). Additionally, it modifies virus evolution rates and selection pressures which can result in the development of virulent virus strains with broadened natural host ranges, higher virus multiplication rates in reservoir hosts, and increased vector transmission efficiencies. Extended heat waves are likely to cause remission of virus disease symptoms in infected plants by reducing their virus contents. In some instances, extended heat waves might destroy virus infections from growing plants where systemic invasion is already incomplete or the virus involved has unstable particles. Protracted heat waves might as well sometimes be sufficiently long to inactivate seed transmission of seed coat contaminants with viruses with unstable particles (Jones and Barbetti, 2012).

Jones (2014) reported the potential effects of high temperatures on potato virus epidemics. Potato-infecting viruses that are more common in warmer climates including Potato leaf roll virus and Potato yellow vein virus are likely to spread from their current habitats to areas of higher latitude previously too cool for them and to formerly cooler highlands in tropical and subtropical regions. On the other hand, the geographical distributions of viruses adapted to cooler regions such as Andean potato latent virus and Potato mop-top virus are expected to contract to areas of higher latitude or higher elevations in mountainous areas in tropical and subtropical areas, including ones previously very cold for the potato plant.

Nancarrow et al. (2014) studied the effects of elevated $\left(10-21^{\circ} \mathrm{C}\right.$, night/ day) or $\left(5-16^{\circ} \mathrm{C}\right.$, night/day) temperatures for the growth of wheat plants infected with Barley yellow dwarf virus. Infected plants grown below high temperatures were larger, developed virus symptoms earlier, and had higher virus titers than plants grown at ambient temperatures. Chung et al. (2015) investigated the effects of various temperature regimes on the speed of systemic invasion following inoculation of Turnip mosaic virus to Chinese cabbage. It took 48 days for the systemic infection to occur at $13^{\circ} \mathrm{C}$ but only for six days at $22-33^{\circ} \mathrm{C}$. The rate of systemic infection increased linearly up to $23^{\circ} \mathrm{C}$. The maximum temperatures for symptoms expression were $23-28^{\circ} \mathrm{C}$. Aguilar et al. (2015) studied the effects of high temperatures upon the synergism interaction between Potato virus $X$ and Plum pox virus infecting Nicotiana benthamiana. The result showed that the titers and virulence of both viruses decreased markedly with mixed infection at $30^{\circ} \mathrm{C}$ compared to $25^{\circ} \mathrm{C}$.

Guerret et al. (2016) investigated the effects of temperature on the manifestation of symptoms in subterranean clover plants infected singly or in mixed infection with Bean yellow mosaic virus (BYMV) and the fungus Kabatiella caulivora. The plants were maintained at $18^{\circ} \mathrm{C}, 20^{\circ} \mathrm{C}$, or $22.5^{\circ} \mathrm{C}$ after BYMV inoculation and inoculated with $K$. caulivora once systemic BYMV symptoms appear. Mixed infections have caused the symptoms of more serious diseases. In sole infections, BYMV symptoms were most pronounced at $18^{\circ} \mathrm{C}$, but $\mathrm{K}$. caulivora developed more severe symptoms at $20^{\circ} \mathrm{C}$ and $22.5^{\circ} \mathrm{C}$. In mixed infections, the severity of the disease followed the pattern developed with BYMV alone as the temperature increased. Also, a synergistic increase in disease severity sometimes occurred at $18^{\circ} \mathrm{C}$, but increases in severity were always additive at $20^{\circ} \mathrm{C}$ and $22.5^{\circ} \mathrm{C}$, indicating the greater BYMV multiplication found in infected leaves at $18^{\circ} \mathrm{C}$ compared with $20^{\circ} \mathrm{C}$ or $22.5^{\circ} \mathrm{C}$.

\subsection{Insect vectors}

Insect vectors are an important means for the transmitting and dispersal of the majority of plant viruses 
(BosquePérez and Eigenbrode, 2011). The viruses transmitted by insect vectors depend on the behavior and dispersal capacity of their vectors (Nault, 1997; Ng JCK and Falk, 2006). Sucking insects, such as aphids, thrips, whiteflies, and leafhoppers, are associated with virus transmission, which can lead to significant crop losses. Temperature is a major and predominant climatic parameter that influences vectors of viruses, occurrence, and herbivores that alter their growth, survival, fecundity, distribution, and abundance (Bale et al., 2002). Insect populations of most virus vectors build up more rapidly in areas with high temperatures and high relative humidity and decrease at low temperatures and high rainfalls (Islam et al., 2017).

Significant changes in the spread and distribution of insect vectors can result from small changes in moderate temperatures. Increasing temperatures alter the physiology of plants by influencing the secondary metabolite pathways, thereby altering the nutritious value of leaves to insect vectors. This alters the replication of the virus within the cells, thus influencing virus systemic movement and acquisition by vectors (Jones, 2016).

Rising temperatures, altering insect population dynamics by accelerating insect phenology, have created an earlier and prolonged colonization because it created the ideal conditions for the insect vectors and their host plants to capture several regions to be extended (Elad and Pertot, 2014; Jones, 2014; Jones and Naidu, 2019; Juroszek et al., 2019; Luck et al., 2011; Trębicki et al., 2016). In addition, rising temperatures can increase the effectiveness of virus transmission from infected to healthy plants by insect vectors. The improved efficiency of such transmission can allow the viruses they transmit to extend their ranges to areas formerly too cold for them to be transmitted successfully. However, distributions of some other viruses might contract from regions with increased temperatures due to reduced virus transmission efficiencies at higher temperatures. Also, long-term heat waves can reduce vector numbers thereby reducing virus epidemics (Canto et al., 2009; Jones and Barbetti, 2012).

Among insect vectors, aphids are the most common and cause for the transmission of $50 \%$ of insect-vectored viruses (Nault, 1997). Aphids respond strongly to small changes in temperatures due to their mobility, short generation times, high reproductive capacity, and the ability to make rapid life history and behavioral changes (Jones, 2016). Another five generations of aphids/year are predicted in warmer weather from a temperature of $2^{\circ} \mathrm{C}$. As a result, the risk of severe epidemics of aphid-transmitted viruses increases as their populations and activities increase. In warmer climates, the survival of aphid vectors is likely to increase with milder winter temperatures, and higher summer temperatures are likely to increase their growth and reproductive rates. A few days with shorter cold spells raise their ability to overwinter, allowing them to enlarge their geographic ranges and enhance the period in which they are active each year. Rising winter temperatures make earlier starts to aphid annual life cycles, increase the number of winged aphids, and encourage their flight activity. Many aphid-borne viruses are most likely to spread in warmer climates under increasing winter and summer temperatures (Jones, 2009; Canto et al., 2009; Jones and Barbetti, 2012).

According to developed formulas to estimate the number of generations of insects under global warming, an increase in temperature of $3{ }^{\circ} \mathrm{C}$ in warmer climates results in seven generations of aphids per year (Yamamura and Kiritani, 1998). The survival of the aphid can be suppressed when temperatures exceed $36^{\circ} \mathrm{C}$ during the summer months, thereby reducing the spread and persistence of the Barley yellow dwarf virus (Parry et al., 2012). The studies conducted by Gao et al. (2012) on the effects of rearing the vector species Acyrthosiphon gossypii (a cotton aphid) on cotton plants at $18^{\circ} \mathrm{C}, 21^{\circ} \mathrm{C}, 24^{\circ} \mathrm{C}, 27^{\circ} \mathrm{C}$, and $30^{\circ} \mathrm{C}$ indicated that the average longevity of adult females was 16, 12, 8, 5, and 3 days, and the average number of offspring per female was 46, 38, 20, 14, and 0 at these temperatures, respectively. The optimal temperature range for its growth was $21-27^{\circ} \mathrm{C}$, while $30^{\circ} \mathrm{C}$ was above the upper limit for reproduction.

Gillespie et al. (2012) found that the population growth of Myzus persicae (green peach aphid) was lower in temperatures $\left(32^{\circ} \mathrm{C}\right.$ and $40^{\circ} \mathrm{C}$ maxima) compared to areas with occasional hot days. Heatwaves also reduce the proportion of winged aphids in the population. Ryalls et al. (2013) investigated the ability of Acyrthosiphon pisum (the pea aphid) to colonize three alfalfa cultivars when temperatures increased from $26^{\circ} \mathrm{C}$ to $30^{\circ} \mathrm{C}$.

Rising temperatures can increase thrips vector populations by accelerating their development rates leading to several generations per year. Since different thrips species have different tempreture limits, global warming is likely to change the composition of their species. For example, Thrips palmi is expected to expand into areas previously too cold for it, displacing vector thrips species adapted to cooler temperatures. This is expected to lead to an increase in new regions of several damaging tospoviruses it transmits. The same assumptions apply to viruses transmitted by leafhoppers, mealybugs, and eriophyid mites (Canto et al., 2009; Jones, 2009; Jones and Barbetti, 2012). Other studies by Yadav and Chang (2014) on Thrips palmi survival, development, fecundity, longevity, and population growth on eggplants at $16^{\circ} \mathrm{C}, 19^{\circ} \mathrm{C}, 22^{\circ} \mathrm{C}, 25^{\circ} \mathrm{C}, 28^{\circ} \mathrm{C}$, and $31^{\circ} \mathrm{C}$ showed that its egg-to-adult developmental period declined from 36 to 10 days as the temperature rose from $16^{\circ} \mathrm{C}$ to $31^{\circ} \mathrm{C}$. Fecundity was very high at $25^{\circ} \mathrm{C}$ and low at $16^{\circ} \mathrm{C}$. Its population trend index was very high at $25^{\circ} \mathrm{C}$ and very low at $16^{\circ} \mathrm{C}$, and the ideal development temperature was $25^{\circ} \mathrm{C}$. Fecundity was very high at $25^{\circ} \mathrm{C}$ and low very high at $16^{\circ} \mathrm{C}$. Its human population index was very high at $25^{\circ} \mathrm{C}$ and very low at $16^{\circ} \mathrm{C}$, and the ideal development temperature was $25^{\circ} \mathrm{C}$.

Whitefly vectors are also active in responding strongly to temperature changes due to their short generation 
times, high reproductive capacity, and the ability to generate rapid life history and behavioral changes (Jones, 2016). For example, due to the increase in winter temperatures in places formally too cold for it in winter, Bemisia tabaci is tending to displace Trialeurodes vaporariorum which increases its distribution in previously cooler areas. Also, this shift in vector distribution influences whitefly-transmitted virus distributions in various parts of the world, and the destructive epidemics of $B$. tabaci-transmitted begomoviruses are becoming more widespread (Jones and Barbetti, 2012).

\section{Influence of Rainfall}

Weather extremes result in excessive rainfall and flooding as well as severe drought (Anayamba et al., 2014). Such weather extremes can create exceptional conditions for extensive virus disease outbreaks in cultivated and natural vegetation. The study carried out in Ethiopia by Regassa et al. (2020) on the epidemic of maize lethal necrosis (MLN) which is caused by co-infection of Maize chlorotic mottle virus with Sugarcane mosaic virus indicated that high prevalence and disease incidence of MLN were highest at altitudinal ranges of and 1700-2000 m.a.s.1 as compared to higher altitude of $>2000$ m.a.s.l. Maize grown at an altitude range of 1700 to 1200 m.a.s.l receives moderate rainfall (Abate et al., 2015), and characterized by warm and semi-humid weather conditions, which could be conducive environment for insect vectors development and spread that result in increased prevalence and disease incidence of MLN. While, higher altitude areas (>2000 m.a.s.l) of Ethiopia are characterized by high rainfall (Abate et al., 2015) and highland (cool temperature), which could hinder insect vector reproduction and ease of mobility to spread the viruses. Insect populations of most virus vectors build up faster in areas with high temperature and high relative humidity, and decline at low temperature and high rainfalls (Islam et al., 2017).

Epidemics of insect-transmitted plant viruses such as arthropods are likely to alter significantly as climate change alters the world's rainfall patterns, flood events and drought happen to more extreme and wet seasons become increasingly less predictable in many parts of the world. The increased repeated occurrence/frequency of heavy rainfall, extreme drought, or flood events expected to arise from climate change is possible to influence plant virus disease epidemics in various ways. An increasing frequency of heavy rainfall events is likely to slow the virus prevalence and incidence by washing insect vectors like thrips, whiteflies and aphids off foliage, thus reducing vector density. Water logging as a result of flooding kills pupal life stages of thrips vectors in the soil, consequently reducing epidemics of the viruses they transmit by reducing insect vector densities. Flooding within annual crop growing period enhances the subsequent growth of weed which acts as reservoirs of plant viruses and insect vectors, and its occurrence outside growing seasons increases following growth of such reservoirs. On the other hand, prolonged drought stress on crop plants can limit insect vector population size and also limit the size of reservoirs of viruses and vectors (weed and volunteer crop) (Jones, 2016).

With the spread of contact-transmitted viruses, the high frequency and intensity of summer storms linked with heavy rainfall or hail that increase rain splash and wounding of plants, and also provide moisture are expected to accelerate their spread leading to a severe virus epidemics. Additionally, both flood and drought can influence survival of unprotected virus particles in contaminated soil and their abilities to act as sources of inoculum for spread to susceptible crops. For example, the dry, compacted, or waterlogged soils typical of drought or flooding, respectively, favor survival of the stable, contact-transmitted virus Tobacco mosaic virus in plant debris in soil but well-aerated soils favor its inactivation. An increase in flooding from storms would speed up water-borne virus dispersion through irrigation and drainage channels, rivers and streams; however drought environment would have the opposite effect (Jones and Barbetti, 2012).

\section{References}

Abate, T., Shiferaw, B., Menkir, A., Wegary, D., Kebede, Y., Tesfaye, K., Kassie, M., Bogale, B., Tadesse, B., Keno, T. (2015). Factors that transformed maize productivity in Ethiopia. Food Security 17 (5), 965-981.

Agrios, G. N. (2005). Plant Pathology. $5^{\text {th }}$ eddition. Elsevier Academic Press, 952.

Aguilar, E., Allende, L., del Toro, F.J., Chung, B.-N., Canto, T., Tenllado, F. (2015). Effects of elevated $\mathrm{CO}_{2}$ and temperature on pathogenicity determinants and virulence of Potato virus X/Potyvirus-associated synergism. Molecular Plant-Microbe Interactions 28(12), 1364-1373.

Anayamba, A., Small, J.L., Britch, S.C., Tucker, C.J., Pak, E.W., Reynolds, C.A., Crutchfield, J., Linthicum, K.J. (2014). Recent weather extremes and impacts on agricultural production and vector-borne disease outbreak patterns. PLoS One 9 (3), e92538. http://dx.doi.org/10.1371/journal.pone.0092538.

Bale, J. S., Masters, G. J., Hodkinson, I. D., Awmack, C., Bezemer, T. M., Brown, V. K., Butterfield, J., Buse, A., Coulson, J. C., Farrar, J., Good, J. E. G., Harrington, R., Hartley, S., Jones, T. H., Lindroth, R. L., Press, M. C., Symrnioudis, I., Watt, A. D., Whittaker, J. B. (2002). Herbivory in global climate change research: direct effects of rising temperature on insect herbivores. Global Change Biol 8, 1-16.

Bloomfield, J. P., Williams, R. J, Gooddy, D. C., Cape, J. N., Guha, P. (2006). Impacts of climate change on the fate and behaviour of pesticides in surface and groundwater - a UK perspective. Science of the Total Environment 369, 163-77. 
Bosque-Pérez, N. A., Eigenbrode, S. D. (2011). The influence of virus-induced changes in plants on aphid vectors: insights from luteovirus pathosystems. Virus Research 159(2), 201-205.

Canto, T., Aranda, M. A., Fereres, A. (2009). Climate change effects on physiology and population processes of hosts and vectors that influence the spread of hemipteran-borne plant viruses. Glob. Chang. Biol. 15, 18841894.

Cox, B. A., Luo, H., Jones, R. A. C. (2014). Polymyxa graminis isolates from Australia: identification in wheat roots and soil, molecular characterization and wide genetic diversity. Plant Dis. 98, 1567-1575.

Elad, Y., Pertot, I. (2014). Climate change impacts on plant pathogens and plant diseases. Journal of Crop Improvement 28(1), 99-139.

Gao, G.-Z., Perkins, L.E., Zalucki, M.P., Lu, Z.-H., Ma, J.-H. (2012). Effect of temperature on the biology of Acyrthosiphon gossypii (Mordvilko) (Homoptera: Aphididae) on cotton. J. Pestic. Sci. 86, 167-172.

Geering, A. D. W., Randles, J. W. (2012). Virus Diseases of Tropical Crops. eLS.

Gillespie, D. R., Nasreen, A., Moffat, C. E., Clarke, P., Roitberg, B. D. (2012). Effects of simulated heat waves on an experimental community of pepper plants, green peach aphids, and two parasitoid species. Oikos 1321, $149-159$.

Guerret, G. L., Barbetti, M. J., You, M.J., Jones, R. A. C. (2016). Effects of temperature on disease severity in plants of subterranean clover infected singly or in mixed infection with Bean yellow mosaic virus and Kabatiella caulivora. J. Phytopathol. in press.

Islam, W., Zhang, J., Adnan, M., Noman, A., Zaynab, M., Wu, Z. (2017). Plant virus ecology: a glimpse of recent accomplishments. Appl. Ecol. Environ. Res. 15 (1), 691-705.

Jones A.C. (2004). Using epidemiological information to develop effective integrated virus disease management strategies. Virus Research 100, 5-30.

Jones, R. A. C. (2001). Developing integrated disease management strategies against non-persistently aphid-borne viruses: A model program. Int. Pest Man. Rev. 6, 15-46.

Jones, R. A. C. (2001). Developing integrated disease management strategies against non-persistently aphid-borne viruses: a model program. Integr. Pest Manag. Rev. 6, 15-46.

Jones, R. A. C. (2004). Using epidemiological information to develop effective integrated virus disease management strategies. Virus Res. 100, 5-30.

Jones, R. A. C. (2009). Plant virus emergence and evolution: origins, new encounter scenarios, factors driving emergence, effects of changing world conditions, and prospects for control. Virus Res. 141, 113-130.

Jones, R. A. C. (2014). Virus disease problems facing potato industries worldwide: viruses found, climate change implications, rationalising virus strain nomenclature and addressing the Potato virus $\mathrm{Y}$ issue. In: Navarre, R., Pavek, M.J. (Eds.), The Potato: Botany, Production and Uses. CABI, Wallingford, UK, pp. 202-224.

Jones, R. A. C. (2016). Future Scenarios for Plant Virus Pathogens as Climate Change Progresses. Advances in Virus Research, 87-147.

Jones, R. A. C., Barbetti, M. J. (2012). Influence of climate change on plant disease infections and epidemics caused by viruses and bacteria. CAB Rev. 7 (22), 1-32. http://www.cabi. org/cabreviews.

Jones, R. A. C., Naidu, R. A. (2019). Global Dimensions of Plant Virus Diseases: Current Status and Future Perspectives. Annu Rev Virol 6(1), 387-409.

Jones, R. A. C., Salam, M. U., Maling, T. J., Diggle, A. J., Thackray, D. J. (2010). Principles of Predicting Plant Virus Disease Epidemics. Annual Review of Phytopathology, 48(1), 179-203.

Juroszek, P., Racca, P., Link, S., Farhumand, J., Kleinhenz, B. (2019). Overview on the review articles published during the past 30 years relating to the potential climate change effects on plant pathogens and crop disease risks. Plant Pathology.

Luck, J., Spackman, M., Freeman, A., Trebicki, P., Griffiths, W., Finlay, K., Chakraborty, S. (2011). Climate change and diseases of food crops. Plant Pathol. 60, 113-121.

Mehle, N., Ravnikar, M. (2012). Plant viruses in aqueous environment - survival, water mediated transmission and detection. Water Res. 46, 4902-4917.

Mitchell, S. E., Rogers, E. S., Little, T. J., Read, A. F. (2005). Host-parasite and genotype-by environment interactions: temperature modifies potential for selection by a sterilizing pathogen. Evolution 59 (1), 70-80.

Nancarrow, N., Constable, F. E., Finlay, K. J., Freeman, A. J., Rodoni, B. C., Trebecki, P., Vassiliadis, S., Yen, A.L., Luck, J.E., 2014. The effect of elevated temperature on Barley yellow dwarf virus-PAV in wheat. Virus Res. 186, 97-103.

Nault, L. R. (1997) Arthropod transmission of plant viruses - a new synthesis. Ann Entomol Soc Am 90, 521-541.

Ng, J. C. K., Falk, B. W. (2006). Virus-vector interactions mediating no persistent and semi persistent transmission of plant viruses. Annu Rev Phytopathol 44, 183-212.

Parry, H. R., Macfadyen, S., Kriticos, D. J. (2012). The geographical distribution of Yellow dwarf viruses and their aphid vectors in Australian grasslands and wheat. Australasian Plant Pathology 41(4), 375-387.

Pautasso, M., Doring, T. F., Garbelotto, M., Pellis, L. and Jeger, M. J. (2012). Impacts of climate change on plant 
diseases-opinions and trends. European Journal of Plant Pathology. doi: 10.1007/s10658-012-9936

Regassa, B., Abraham, A., Fininsa, C., Wegary, D., Wolde-Hawariat, Y. (2020). Distribution of maize lethal necrosis epidemics and its association with cropping systems and cultural practices in Ethiopia. Crop Protection, 134, 105151. doi:10.1016/j.cropro.2020.105151

Ryalls, J. M. W., Riegler, M., Moore, B. D., Lopaticki, G., Johnson, S. N. (2013). Effects of elevated $\mathrm{CO}_{2}$ on above ground-below ground systems: a case study with plants, their mutualistic bacteria and root/shoot herbivores. Front. Plant Sci. 4, 445. http://dx.doi. org/10.3389/fpls.2013.00445.

Sastry, K. S., Zitter, T. A. (2014). Management of virus and viroid diseases of crops in the tropics, Plant virus and viroid diseases in the tropics. Springer, pp. 149-480.

Thackray, D. J., Diggle, A. J., Berlandier, F. A., Jones, R. A. C. (2004). Forecasting aphid outbreaks and epidemics of Cucumber mosaic virus in lupin crops in a Mediterranean-type environment. Virus Res. 100, 67-82.

Trebicki, P., Nancarrow, N., Cole, E., Bosque-Perez, N. A., Constable, F., Freeman, A. J., Rodoni, B., Yen, A. L., Luck, J. E., Fitzgerald, G. J. (2015). Virus disease in wheat predicted to increase with a changing climate. Glob. Clim. Change 21, 3511-3519.

Yadav, R., Chang, N. T. (2014). Effects of temperature on the development and population growth of melon thrips, Thrips palmi, on eggplant, Solanum melongena. J. Insect Sci. 14 (1). http://dx.doi.org/10.1093/jis/14.1.78. 